\title{
CENETIC ANALYSIS OF POLYKARYOCYTOSIS BY HERPES SIMPLEX VIRUS
}

\author{
II. RECOMBINATION BETWEEN VIRUSES WITH \\ NON-FUSING AND FUSING ABILITY
}

\author{
SHIGERU YAMAMOTO AND HIDEFUMI KABUTA \\ Department of Microbiology, Kurume University School of Medicine, \\ Kurume, 830, Japan
}

(Received for publication November 16, 1976)

\begin{abstract}
Mixed infection with non-fusing (S) and fusing (G) viruses produced the recombinant (L) which was non-fusing but formed the plaque intermediate in size between parents. Genetic analysis in combination with IDU-resistance (Ir) demonstrated that the progeny designated as LIS (IDUsensitive), LIr and GIr were produced at the ratio of $2: 2: 1$ by genetic recombination between $\mathrm{SI}^{\mathrm{r}}$ and GIS, leading the hypothesis that cell fusion resulting in polykaryocytosis can be expressed by two cistrons each of which determines $L$ character when functioning separately, and recombination units between these $\mathrm{L}$ cistrons could be calculated to be 13.0. Further cross experiments using the L-type recombinants suggested that additional cistron ( $\mathbf{s}$ ) would participate in the process involved in cell fusion or that the intracistronic crossovers are possible.
\end{abstract}

\section{INTRODUCTION}

The occurrence of recombinants possessing an ability to cause cytopathogenic effect intermediate between parents was previously reported with a cross experiment between strain $\mathrm{HF}$ (type 1) and KY (type 2) which forms a large polykaryocyte and round cells by infection, respectively (Kabuta, 1974). Moreover, the recent work (Yamamoto et al., 1975) has demonstrated that the parental viruses which cause polykaryocytosis were produced by the crosses between such the recombinants and also between one of the recombinants and various virus strains differing in their origin. These facts suggest that the expression of polykaryocytosis by herpes simplex virus is determined by more than two cistrons.

The present work was undertaken to obtain detailed genetic information about polykaryocytosis by herpes simplex virus. For this purpose, a clone from a fresh isolate and a mutant derived from the clone were used; the former causes the infected cells to round and the latter causes them to fuse resulting in formation of large flat polykaryocytes. In a preliminary cross experiment between them, the production of the progeny virus differing in character from the parents was already reported (Yamamoto et al., 1972). The genetic products including such the progeny from the cross were investigated in detail in the present experiment. 


\section{MATERIALS AND METHODS}

\section{Cells}

Cells cloned from GMK cells (continuous cell line of African green monkey kidney) were grown in the mixture of 7 parts of Hanks saline containing 0.5 $\%$ lactalbumin hydrolysate and 3 parts of MEM (Eagle's essential medium) supplemented with $10 \%$ heated $\left(56^{\circ} \mathrm{C}, 30\right.$ minutes) bovine serum, and used for titrations and characterizations of viruses. RK cells (serially passaged cells derived from rabbit kidney) were grown in MEM supplemented with $10 \%$ heated bovine serum.

\section{Viruses}

Isolation and properties of $\mathrm{S}, \mathrm{L}$ and $\mathrm{G}$, and their IDU (5-iodo-2'-deoxyuridine)-resistant mutants were already described (Yamamoto et al., 1972 a, b). Briefly, $S$ was plaque-purified from frésh isolate, strain $\mathrm{YH}$, which had been isolated from herpetic lesion of lip. The sequential spontaneous mutations occurred like as $\mathrm{S} \rightarrow \mathrm{L} \rightarrow \mathrm{G}$. Thus, $\mathrm{L}$ and $G$ mutants were obtained by cloning a single plaque formed by the mutant viruses. IDU-resistant mutant for each virus was isolated by cloning of single plaques which were formed under the agar containing IDU at the concentration of $500 \mu \mathrm{g} / \mathrm{ml}$, and additional three times clonings were carried out without IDU. The IDU-resistance were stable even after serial ten passages of the virus in GMK or RK cells, and designated as $\mathrm{I}^{\mathrm{r}}$. Original IDU-sensitive virus was designated as I $^{\mathrm{S}}$.

Viruses were titrated by plaque technique. GMK cell monolayers in $2-\mathrm{oz}$ bottles were washed twice with PBS (phosphate-buffered saline) and inoculated with $0.2 \mathrm{ml}$ of virus dilutions. After adsorption for two hours at $37^{\circ} \mathrm{C}$, the cultures were overlaid with four $\mathrm{ml}$ of MEM containing $2.5 \%$ bovine serum, $1.5 \%$ bacto-agar and protamine sulfate at a concentration of $400 \mu \mathrm{g} / \mathrm{ml}$. The monolayers were stained after three days incubation at $37^{\circ} \mathrm{C}$ by secondary overlay with three $\mathrm{ml}$ of agar medium containing neutral red and the plaques were counted the following day.

\section{Characterization of viruses}

S, $L$ and $G$ can be differentiated by their plaque size and CPE (cytopathogenic effect). $S$ forms the plaque of 0.2 to $0.8 \mathrm{~mm}$ in size and renders the infected cells round which are often accompanied with clumping of the round cells. The plaque formed by $\mathrm{L}$ is approximately $1.5 \mathrm{~mm}$ in size and composed of round cells and occasionally contains small polykaryocytes. G forms a large flat polykaryocyte by cell fusion and produce the clear largest plaque of approximately $2.5 \mathrm{~mm}$ in size. Thus, the plaque or CPE characters of these viruses were checked under agar or fluid medium. IDU-resistance was tested by comparing plaque formation under agar with and without IDU at the concentration of $300 \mu \mathrm{g} / \mathrm{ml}$ (Yamamoto and Kabuta, 1973).

\section{Recombination experiments}

RK or GMK cells previously washed three times with PBS were inoculated with mixture of $\mathrm{SI}^{\mathrm{r}}$ and GIS. After adsorption for two hours at $37^{\circ} \mathrm{C}$, the cell monolayers were washed seven times with PBS in order to eliminate unadsorbed virus. Four $\mathrm{ml}$ of MEM were added to the cultures and incubated at $37^{\circ} \mathrm{C}$ for 21 hours. The progeny viruses were harvested by freeze-thawing followed by sonication at $20 \mathrm{kc} / \mathrm{sec}$ for two minutes and plaque-assayed on GMK cells. Multiplicity of infection (MOI) 
was obtained by the following ;

$$
\mathrm{MOI}=\frac{\mathrm{A}-\mathrm{B}}{\mathrm{N}}
$$

where $\mathrm{A}$ and $\mathrm{B}$ is total PFU (plaque forming units) of inoculated and unadsorbed virus, respectively, and $\mathrm{N}$ is number of cells. PFU of unadsorbed virus (B) were determined by titrating the combined fluid of inoculum and washings after virus adsorption.

The progeny viruses from a cross of $\mathrm{SI}^{\mathbf{r}} \times \mathrm{GI}^{\mathbf{S}}$ were assayed by plaque formation under agar with and without IDU $(300 \mu \mathrm{g} / \mathrm{ml})$, and recombination frequencies $(\mathrm{RF})$ were calculated from the relationship;

$$
\mathrm{RF}(\%)=\frac{2 \times \mathrm{X}}{\mathrm{Y}} \times 100-\mathrm{C}
$$

where $\mathrm{X}$ represents the titer of large plaque formers under agar with IDU and $Y$ is the total titer of progeny viruses which is titrated without IDU. $\mathrm{C}$ is given as the correction for the presence of $\mathrm{GI}^{\mathrm{r}}$ in the progeny from single infection with $\mathrm{SI}^{\mathbf{r}}$ and $\mathrm{GI}^{\mathrm{s}}$, but in the present experiment no or only negligible $\mathrm{GI}^{\mathrm{r}}$ was detected in the progeny from single infection with $\mathrm{SI}^{\mathrm{r}}$ or $\mathrm{GI}^{\mathrm{S}}$, respectively. As the yield of reciprocal recombinants at the same frequencies was demonstrated with herpes simplex virus in the previous study (Yamamoto and Kabuta, 1973), it would be reasonable to express $R F$ as twice the frequency of IDU-resistant recombinants $(\mathrm{X})$.

\section{RESULTS}

\section{Recombination between CPE and IDU characters}

Monolayer cultures of RK or GMK cells $\left(1.4 \times 10^{6}\right.$ cells/bottle) were singly or mixedly infected with $\mathrm{SI}^{r}$ and GIS at the MOI of approximatly 2.5 each. At the same time, virus mixture at the same concentration as above was held at $37^{\circ} \mathrm{C}$ for 3 and 21 hours to ascertain absence of genetic interaction in cell

TABLE 1

Yields of progeny with respect to CPE and IDU characters from single

\begin{tabular}{|c|c|c|c|c|c|c|c|}
\hline \multirow{2}{*}{ Cell } & \multirow{2}{*}{$\begin{array}{l}\text { Viruses } \\
\text { (parent) }\end{array}$} & \multicolumn{4}{|c|}{ Titers of progeny, PFU $/ \mathrm{ml}$} & \multirow{2}{*}{$\%$ of $\mathrm{GI}$} & \multirow{2}{*}{$\mathrm{RF}^{*}$} \\
\hline & & $\mathrm{S}$ & G & Total & G I $r$ & & \\
\hline $\mathrm{RK}$ & $\begin{array}{l}\mathrm{SI}^{\mathrm{r}} \\
\mathrm{GI} \\
\mathrm{SI}^{\mathrm{r}} \times \mathrm{GIS}^{\mathrm{s}}\end{array}$ & $\begin{array}{l}4.5 \times 10^{7} \\
2.6 \times 10^{7}\end{array}$ & $\begin{array}{l}3.2 \times 10^{7} \\
5.0 \times 10^{7 * *}\end{array}$ & $\begin{array}{l}4.5 \times 10^{7} \\
3.2 \times 10^{7} \\
7.6 \times 10^{7}\end{array}$ & \begin{tabular}{|c|}
$<5.0 \times 10^{3}$ \\
$1.1 \times 10^{4}$ \\
$7.4 \times 10^{6 * *}$
\end{tabular} & $\begin{array}{r}<0.01 \\
0.03 \\
9.74\end{array}$ & 19.5 \\
\hline GMK & $\begin{array}{l}\mathrm{SI}^{r} \\
\mathrm{GI}^{\mathrm{s}} \\
\mathrm{SI}^{\mathrm{r}} \times \mathrm{GIS}^{\mathrm{s}}\end{array}$ & $\begin{array}{l}3.2 \times 10^{7} \\
2.1 \times 10^{7}\end{array}$ & $\begin{array}{l}3.3 \times 10^{8} \\
4.2 \times 10^{7 * *}\end{array}$ & $\begin{array}{l}3.2 \times 10^{7} \\
3.3 \times 10^{8} \\
6.3 \times 10^{7}\end{array}$ & $\begin{array}{c}<5.0 \times 10^{3} \\
1.6 \times 10^{5} \\
6.8 \times 10^{6 * *}\end{array}$ & $\begin{array}{r}<0.02 \\
0.05 \\
10.79\end{array}$ & 21.6 \\
\hline Cell free & $\mathrm{SI}^{\mathrm{r}}+\mathrm{GIS}$ & $\begin{array}{c}3 \mathrm{hrs} \text { at } \\
1.0 \times 10^{7} \\
20 \mathrm{hrs} \text { at } \\
2.2 \times 10^{5}\end{array}$ & $\begin{array}{l}{ }^{\circ} \mathrm{C} \\
1.5 \times 10^{7} \\
{ }^{\circ} \mathrm{C} \\
2.1 \times 10^{5}\end{array}$ & $\begin{array}{l}2.5 \times 10^{7} \\
4.3 \times 10^{5}\end{array}$ & $\begin{array}{l}1.0 \times 10^{4} \\
2.5 \times 10^{5}\end{array}$ & $\begin{array}{l}0.04 \\
0.06\end{array}$ & \\
\hline
\end{tabular}
and mixed infection with $S I^{r}$ and $G I^{S}$, and recombination frequencies

* Recombination frequency between I and CPE characters.

** Titers including L-type recombinants. 
free system. The results were shown in Table 1. In the mixed infection, the CPE was characterized as round cells as well as in single infection with $\mathrm{SI}^{\mathrm{r}}$. However, it was revealed by subsequent assay on GMK cell monolayers that the mixed infection resulted in the production of both parental genotypes. This phenomenon was in agreement with the results of several investigators (Roizman, 1962 ; Keller, 1976). GMK cells infected with GIS produced the progeny approximately ten times those from RK cells. Such the difference of yield between in GMK and RK cells infected with GIS were previously reported (Yamamoto et al., 1972 a) but when the cells were simultaneously infected with $\mathrm{SI}^{\mathrm{r}}$ the yield of $G$ genotype from infected GMK cells was comparable to that from RK cells either single or mixedly infected.

As well as reported earlier (Yamamoto et al., $1972 \mathrm{~b}$ ), the mixed infection in the present experiment also produced some viruses which formed the plaque intermediate in size between parents (Fig. 1). Cytopathogenicity and plaque size of the intermediate plaque formers could not be differentiated from L mutant described earlier (Yamamoto et al., 1972 a) which had been derived from $\mathrm{S}$ by spontaneous mutation, that is, the plaque formed by both viruses is appro-

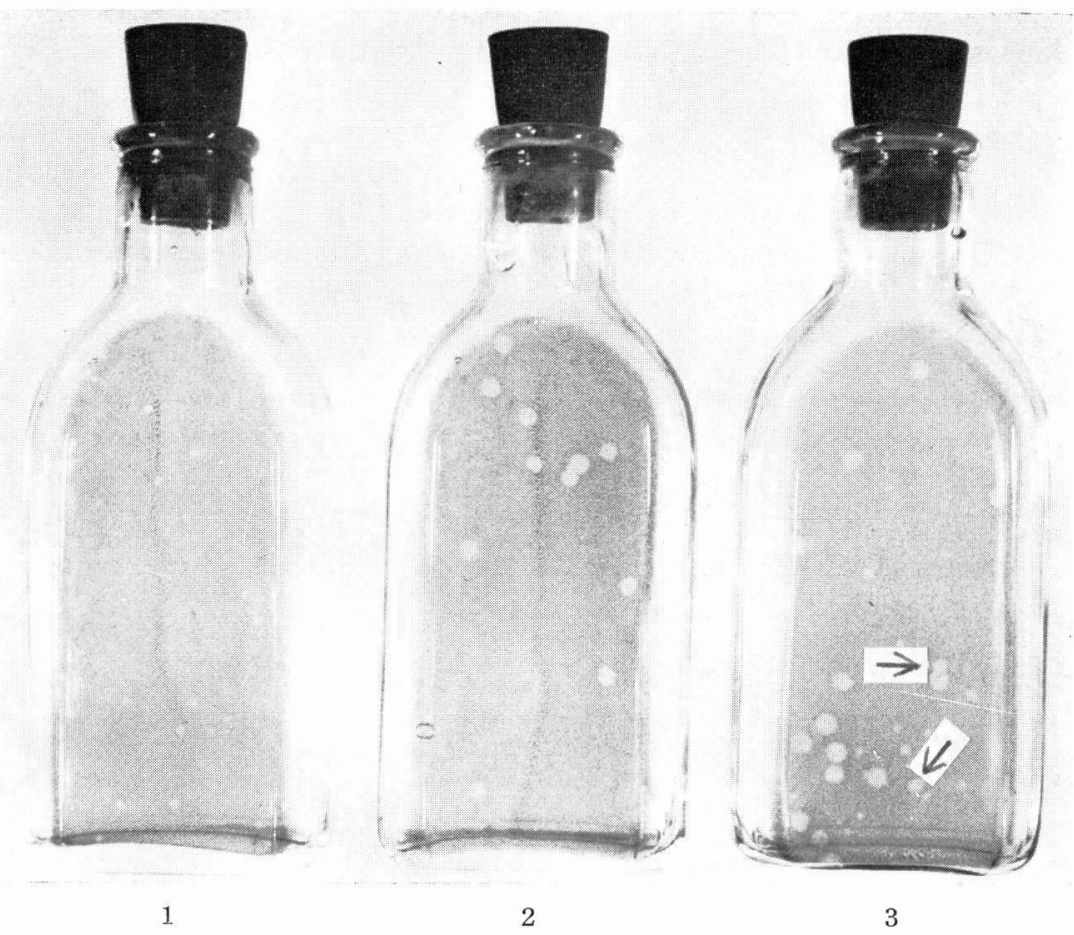

Fig. 1 Plaques formed by progeny from single and mixed infection with SIr and GIS.

1. $\mathrm{SI}^{\mathrm{r}}$

2. $\mathrm{GIS}^{\mathrm{S}}$

3. $\mathrm{SI}^{\mathrm{r}} \times \mathrm{GIS}$

Arrows indicate the plaques formed by L-type recombinants. 
ximately $1.5 \mathrm{~mm}$ in size and composed of round cells and occasionally contains small polykaryocytes. This recombinant will be therefore designated as $\mathrm{L}$ in the followings. As shown in Table 1, the recombination frequency between $\mathrm{CPE}$ and IDU characters were 19.5 and 21.6 with RK and GMK cells, respectively, suggesting practically the same recombination frequencies with both cells.

\section{Analysis of progeny}

Production of $\mathrm{L}$ recombinant suggests that the expression of polykaryocyte by herpes simplex virus associates with more than two cistrons as reported previously (Yamamoto et al., $1972 \mathrm{~b}$, 1975). In order to characterize the CPE and IDU-resistance of individual progeny viruses produced by the cross in RK cells were examined following the diagram presented in Fig. 2: (a) The progeny virus was plated to yield approximately ten plaques per bottle. All $\mathrm{L}$ plaques formed were picked and placed in individual tubes containing two $\mathrm{ml}$ of diluent. Plaque suspensions were frozen and thawed one time, and stand until the agar debris sedimented. The resultant supernatant virus suspensions were tested for IDU character. (b) The progeny virus was plated to yield approximately two large plaques per bottle in the presence of IDU. All large plaques which could be regared as $\mathrm{LI}^{\mathrm{r}}$ or $\mathrm{GI}^{\mathrm{r}}$ were cloned, and tested again for CPE by inoculating onto cell monolayers maintained in MEM without IDU. As shown in Fig. 2, out of $149 \mathrm{~L}$ clones, 77 were $\mathrm{I}^{\mathrm{S}}$ and 72 were $\mathrm{I}^{\mathrm{r}}$. These numbers can be regarded as the production of $\mathrm{LI}^{\mathrm{S}}$ and $\mathrm{LI}^{\mathrm{r}}$ to be at the same ratio or $1: 1$. On the other hand, $138 \mathrm{LI}^{\mathrm{r}}$ and $70 \mathrm{GI}^{\mathrm{r}}$ out of 208 clones were found in the progeny showing that the ratio was $2: 1$. Thus, it can be concluded that the cells mixedly infected with $\mathrm{SI}^{r}$ and GIS produced the three recombinants characterized as $\mathrm{LI}^{\mathrm{S}}, \mathrm{LI}^{\mathrm{r}}$ and $\mathrm{GI}^{\mathrm{r}}$ at the ratio of $2: 2: 1$, respectively, in the population of the progeny. Evidence

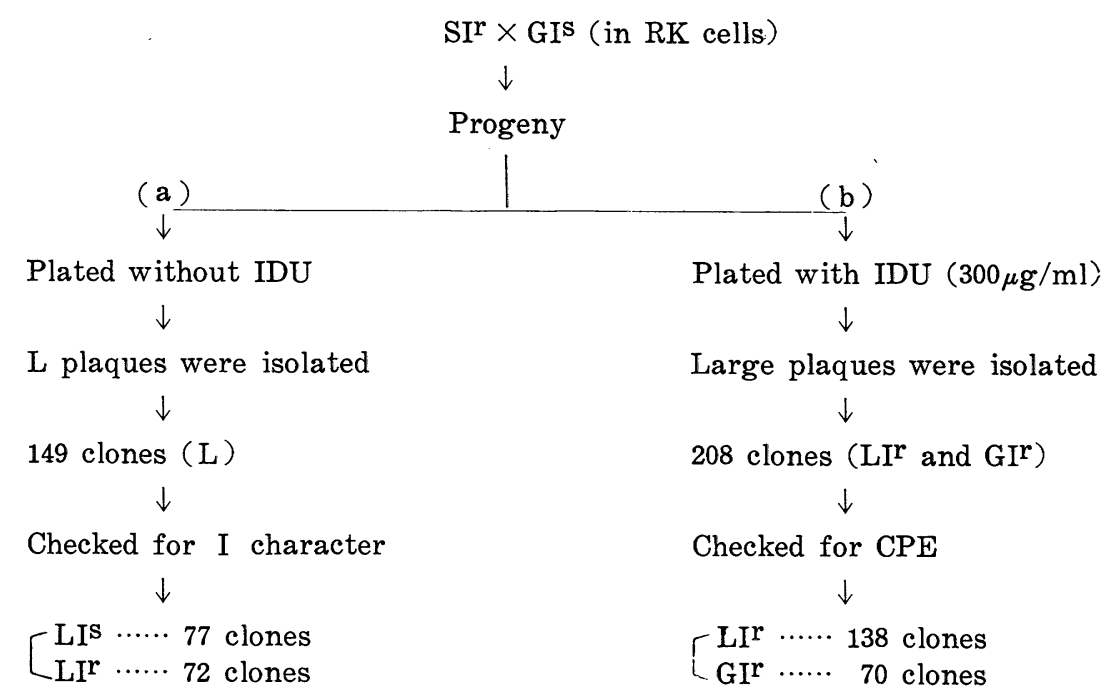

Fig. 2 Analysis of progeny from a cross of SIr $\times$ GIS. 
for the stability of these recombinants was demonstrated by the fact that five clones each of the recombinant types maintained their CPE and I characters even after ten cycles of passages in GMK or RK cells.

If the stepwise mutation of $\mathrm{S} \rightarrow \mathrm{L} \rightarrow \mathrm{G}$ occurs in a single gene, it is not likely that $\mathrm{L}$ genotype ( $\mathrm{LI}^{\mathrm{S}}$ and $\mathrm{LI}^{\boldsymbol{r}}$ ) is produced by a cross between $\mathrm{SI}^{\mathrm{r}}$ and $\mathrm{GI}^{\mathrm{S}}$. Therefore, it will be reasonable to consider that two (or more) genes located at different loci are associated with the expression of CPE charracter. One hypothesis is that the viral genome contains two genes which determine each $L$ and $G$ character. According to this hypothesis the possible gene sequences related to $\mathrm{CPE}$ and I characters on viral chromosome are L-G- $\mathrm{I}^{r}, \mathrm{~L}-\mathrm{I}^{\mathrm{r}}-\mathrm{G}$, or $\mathrm{I}^{\mathrm{r}}-\mathrm{L}-\mathrm{G}$. Appearance of recombinants by crosses between $\mathrm{SI}^{\mathbf{r}}$ and $\mathrm{GI}^{\mathrm{S}}$ in the diagram below where two lines represent parent chromosomes and crossed broken lines represent the sites of crossovers. For case (1) it is expected that equal number of GIS and $\mathrm{LI}^{\mathbf{r}}$ would be produced by crossover between $\mathrm{L}$ and G locus, and SIS and GI ${ }^{r}$ would be produced by crossover between $G$ and $I^{r}$ locus. Consequently, no LIS genotype could be produced. For case (2) GIr and $\mathrm{LI}^{\mathrm{S}}$ would be produced in equal numbers, but it does not agree with the results $\left(\mathrm{LI}^{\mathrm{S}}: \mathrm{GI}^{\mathrm{r}}=2.1\right.$ ) in the present experiment. For case (3) no $\mathrm{LI}^{\mathrm{r}}$ would be produced by any crossovers. It can be therefore concluded that this hypothesis is not consistent with the experimental results obtained. In every case, recombinants which would be produced by double crossovers are neglected because the production of such the recombinants will be relatively in very small amount from the assumption that single crossovers are more frequent than double crossovers.
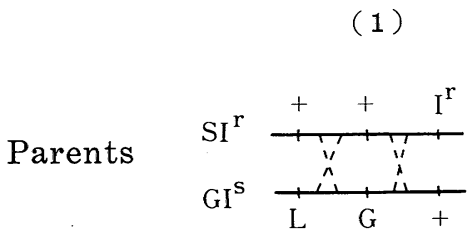

$$
\begin{aligned}
\text { Recombinants } & \mathrm{GI}^{\mathrm{S}}=\mathrm{LI}^{\mathrm{r}} \\
\text { expected } & \mathrm{SI}^{\mathrm{S}}=\mathrm{GI}^{\mathrm{r}}
\end{aligned}
$$

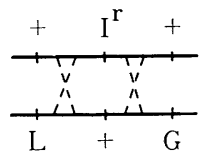

$\mathrm{GI}^{\mathrm{S}}=\mathrm{LI}^{\mathrm{r}}$

$\mathrm{GI}^{\mathrm{r}}=\mathrm{LI}^{\mathrm{S}}$
(3)

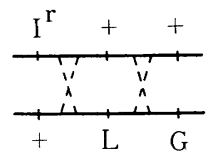

$\mathrm{GI}^{\mathrm{r}}=\mathrm{SI}^{\mathrm{S}}$

$\mathrm{GI}^{\mathrm{r}}=\mathrm{LI}^{\mathrm{S}}$
Another hypothesis is that $\mathrm{G}$ character is expressed in combination of two genes which give rise to $\mathrm{L}$ character when functioning separately. As illustrated in the diagram below, the gene sequences are either of such the two cases as $\mathrm{I}^{\mathrm{r}}$ being inside or outside the two genes which designated as $\mathrm{L}_{1}$ and $\mathrm{L}_{2}$. For case (1), although $\mathrm{LI}^{\mathrm{S}}$ and $\mathrm{LI}^{\mathrm{r}}$ would be produced in equal numbers, no GI $^{r}$ would be produced. The possibility of this gene sequence can therefore be excluded. For case (2), on the other hand, the production of LIS and LI ${ }^{r}$ in equal numbers and also that of $\mathrm{GI}^{\mathrm{r}}$ can be expected which is well consistent with the experimental data. Furthermore, the fact that a small number of SIS was also found in the progeny, although the ratio of yield could not be estimated because of the technical difficulties, gives the additional support to this hypothesis. 
(1)

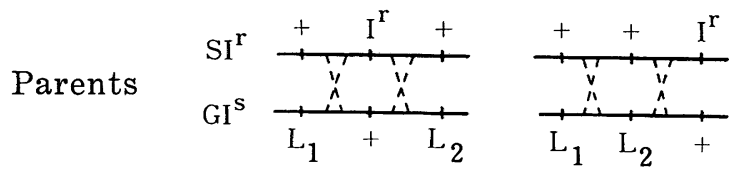

Recombinants

expected

$$
\begin{aligned}
& \mathrm{LI}^{\mathrm{S}}=\mathrm{LI}^{\mathrm{r}} \\
& \mathrm{LI}^{\mathbf{r}}=\mathrm{LI}^{\mathrm{S}}
\end{aligned}
$$

\section{(2)}

$\mathrm{LI} S=\mathrm{LI}^{\mathrm{r}}$
The present experiment showed that recombination frequency between $\mathrm{CPE}$ and $I$ characters is 19.5 and the ratio of $\mathrm{LI}^{\mathrm{S}}$, LI ${ }^{\mathrm{r}}$ and $\mathrm{GI}^{r}$ in the progeny is $2: 2: 1$. Thus, if the recombination frequencies are assumed to be additive, it will be reasonably considered that the recombination frequency is 13.0 between the two $\mathrm{L}$ genes $\left(\mathrm{L}_{1}\right.$ and $\left.\mathrm{L}_{2}\right)$ and 6.5 between $\mathrm{L}_{2}$ and $\mathrm{I}^{\mathrm{r}}$.

\section{Further crosses between $L$ recombinants}

If the hyothesis and gene squence as described above is true, $\mathrm{L}_{1} \mathrm{~L}_{2}$ genotype or $\mathrm{G}$ should be produced with the frequency of $6.5 \%$ by a cross between two recombinants, $L^{S}$ and $L^{r}$. Four clones each of $\mathrm{LI}^{\mathrm{S}}$ and $\mathrm{LI}^{\mathrm{r}}$ recombinants were further plaque-purified and served for cross experiment. All pairwise crosses were performed in RK cells by inoculating $5 \mathrm{PFU}$ of each virus per cell. The progeny were plated on GMK monolayers to score the yield of $\mathrm{G}$ phenotype and the results were shown in Table 2 . No $G$ was produced at all by single infection with either $\mathrm{LI}^{\mathrm{S}}$ or $\mathrm{LI}^{\mathrm{r}}$. G could be detected in the progeny from five crosses out of 28 combinations, but the frequencies of yields were extremely lower than expected although its production was shown only in the crosses between $\mathrm{LI}^{\mathrm{S}}$ and $\mathrm{LI}^{\mathrm{r}}$ as expected from the assumed gene sequence.

TABLE 2

\begin{tabular}{|c|c|c|c|c|c|c|c|c|c|}
\hline & & \multirow{2}{*}{$\begin{array}{c}\text { Single } \\
\text { infection }\end{array}$} & \multicolumn{3}{|c|}{$\mathrm{LIS}^{\mathrm{S}}$} & \multicolumn{4}{|c|}{$\mathrm{LIr}$} \\
\hline & & & 2 & 3 & 4 & 1 & 2 & 3 & 4 \\
\hline \multirow[t]{4}{*}{ LIs } & 1 & $0 / 9000^{*}$ & $0 / 8330$ & $0 / 5853$ & $0 / 7729$ & $0 / 9160$ & $0 / 9938$ & $0 / 6331$ & $0 / 8173$ \\
\hline & 2 & $0 / 12600$ & & $0 / 9280$ & $0 / 8600$ & $0 / 6798$ & $0 / 6545$ & $0 / 7035$ & $0 / 8180$ \\
\hline & 3 & $0 / 8530$ & & & $0 / 7620$ & $0 / 5531$ & $0 / 5996$ & $1 / 4017$ & $0 / 3832$ \\
\hline & 4 & $0 / 9880$ & & & & $1 / 5323$ & $6 / 4413$ & $5 / 4444$ & $2 / 4836$ \\
\hline \multirow[t]{4}{*}{$\mathrm{LI}^{\mathrm{r}}$} & 1 & $0 / 15120$ & & & & & $0 / 5583$ & $0 / 5058$ & $0 / 4589$ \\
\hline & 2 & $0 / 11880$ & & & & & & $0 / 5203$ & $0 / 5174$ \\
\hline & 3 & $0 / 7200$ & & & & & & & $0 / 5503$ \\
\hline & 4 & $0 / 10800$ & & & & & & & \\
\hline
\end{tabular}

Appearance of $G$ phenotype from crosses between $L$-type recombinants

* No. of G plaques / Total no. of plaques 


\section{DISCUSSION}

The combined use of biochemistry and genetics is thought to be very powerful in the study of cell fusion process by herpes simplex virus as well as a variety of biological phenomena. Since the work of Wildy (1955), the recombination with herpes simplex virus has been proven by several authors using temperature-sensitive or other mutants (Kabuta, 1974; Kabuta et al., 1973; Yamamoto and Kabuta, 1973; Yamamoto et al., 1972, 1973, 1975 ; Brown et al., 1973; Schaffer et al., 1974). In addition, the finding of the occurrence of reciprocal recombinants by the genetic exchange taking place in mixedly infected cells (Yamamoto and Kabuta, 1973 ; Brown and Ritchie, 1975) enabled us to approach some viral functions by genetic experiments.

The isolation of mutants of herpes simplex virus which cause cell fusion to result in the formation of large flat polykaryocyte has been reported by a number of investigators (Hoggan and Roizman, 1959 ; Nii and Kamahora, 1961 ; Yamamoto et al., 1972 a ; Brown et al., 1973), but there is little information about the mechanism involved in fusion process. The experiments using several inhibitors (Poste and Reeve, 1972; Gallaher et al., 1973; Ludwig et al., 1974) suggested that the fusion process is an early event during virus replication and involves synthesis of virus-specific glycoproteins.

Detailed genetic studies with herpes simplex virus type 1 have been done by Brown et al. (1973) using ten temperature-sensitive mutants in combination with syn (syncytium) character which corresponds to $G$ described in our present study, and linkage map was constructed by three-factor crosses in which syn gene was given as a standard point on the chromosome. Thus, they made an assumption that syn character would be determined by only one gene. Recently, Keller (1976) failed to find complementation, by which non-fusing CPE or cell rounding would be expected, between syn- variants derived from other strains and assigned the fusion response to a single gene. However, in a series of our genetic investigation about cytopathic response of the infected cells we have demonstrated that the spontaneous mutation from non-fusing to fusing properties occurs in herpes simplex virus through intermediate non-fusing but larger plaque forming mutant, that is, the sequential mutation such as $\mathrm{S} \rightarrow \mathrm{L} \rightarrow \mathrm{G}$ (Yamamoto et al., 1972 a) and that the stepwise mutation will not be due to the change in a single gene but be associated with two or more genes in viral genome (Yamamoto et al., $1972 \mathrm{~b}, 1975)$. This assumption was strongly supported by the present study.

Analysis of the progeny from the cross of $\mathrm{SI}^{\mathbf{r}} \times \mathrm{GI}^{\mathrm{S}}$ gave the result that the recombinants such as LIS, LI ${ }^{r}$ and GI $^{r}$ were produced at the ratio of 2 : $2: 1$. This result is consistent with a hypothesis that $G$ character can be expressed in combination with two genes each of which shows the CPE of infected cells to be rounding if it functions separately. Moreover, it satisfies the gene sequence of $\mathrm{L}_{1}-\mathrm{L}_{2}-\mathrm{I}^{\mathbf{r}}$ among two possible ones. Finding of a recombinant $\mathrm{SI}^{\mathrm{S}}$, which is expected to be produced from the gene sequence assumed strongly supported this hypothesis.

Therefore, the recombination units can be reasonably assumed as 13.0 between $\mathrm{L}_{1}$ and $\mathrm{L}_{2}$, and 6.5 between $\mathrm{L}_{2}$ and $\mathrm{I}^{\mathrm{r}}$ from the experimental values of recombination between CPE and I character $(19.5 \%)$, and the ratio of yield of three recombinants. However, further crosses between recombinants, LIS and. $\mathrm{LI}^{r}$, produced very small number of $\mathrm{G}$ 
virus in contrast with the frequency (6.5\%) expected from the assumed distance between $\mathrm{L}_{1}$ and $\mathrm{L}_{2}$. This possibly suggests, without any insonsistency of the hypothesis discussed above, that:

(1) additional gene(s) possessing $\mathrm{L}$ function further participates in the expression of $\mathrm{G}$ phenotype or (2) recombinant phenotypically expressed as L can be produced by intracistronic c ossovers in either $\mathrm{L}$ gene.

\section{ACKNOWLEDGEMENTS}

Grateful aknowledgement is made to Prof. Masahisa Shingu for his constant interest and guidance in this investigation.

\section{REFERENCES}

BRown, S. M. and Ritchie, D. A. (1975). Genetic studies with herpes simplex virus type 1 : Quantitative analysis of the products from two-factor crosses. Virology, 64, 281-283.

Brown, S.M., Ritchie,D.A. and Subak-Sharpe, J.H. (1973). Genetic studies with herpes simplex virus type 1. The isolation of temperature-sensitive mutants, their arrangement into complementation groups and recombination analysis leading to a linkage map. J. gen. Virol., 18, 329-346.

Gallaher, W.R., Levitan, D.B. and Blough, H. A. (1973). Effect of 2-deoxy-D-glucose on cell fusion induced by Newcastle disease and herpes simplex virus. Virology, 55, 193-201.

Hoggan, M. D. and Roizman, B. (1959). The isolation and properties of a variant of herpes simplex producing multinucleated giant cells in monolayer cultures in the presence of antibody. Amer. J. Hyg., 70, 208-219.

KaBUtA, H. (1974). Genetic recombination between herpes simplex virus (HSV) type 1 and type 2. J. Kurume med. Assoc.,37, 26-39.

Kabuta, H., Yamamoto, S., Miyamoto, T. and Suenaga, Y. (1973). Experiments on the intra- and inter-typic recombination with herpes simplex virus types 1 and 2 . J. Kurume med. Assoc., 36, 243-347.

Keller, J. M. (1976). The expression of the syn ${ }^{-}$gene of herpes simplex virus type 1. I . Morphology of infected cells. Virology, 69, 490-499.

Ludwig, H., Becht, H. and Rott, R. (1974). Inhibition of herpes virus-induced cell fusion by Concanavalin $\mathrm{A}$, antisera, and 2deoxy-D-glucose. J. Virol,, 14, 307-314.

NiI, S. and Kamahora, J. (1961). Studies on the growth of newly isolated herpes simplex virus in vitro. Biken J., 4, 75-96.

Poste, G. and Reeve,P. (1972). Inhibition of virus-induced cell fusion by local anaesthetics and phenothiazine tranquillizers. J. gen. Virol, 16, 21-28.

Roizman, B. (1962). Polykaryocytosis. Cold Spring Harbor Symp. Quant. Biol., 27, 327340 .

Schaffer, P.A., Tevethia, M. J. and BenyeshMelNick, M. (1974). Recombination between temperature-sensitive mutants of herpes simplex virus type 1. Virology, 58, 219-228.

YAMAMOTo, S. and KabUTA, H. (1973). Genetic studies on herpes simplex virus I. Recombi: nation between plaque morphology and IDU (5-iodo-2'-deoxyuridine) resistance. Kurume $\mathrm{M} \in d$. J., 20, 87-93.

Yamamoto, S., Kabuta, H., Imamoto, M. and Matsumoto, H. (1975). Genetic analysis of polykaryocytosis by herpes simplex virus I. Experiments using recombinants from intertypic cross. Kurume Med. J., 22, 71-78.

Yамамото, S., Kabuta, H. and Miyamoto, T. (1973). Genetic studies on herpes simplex virus II. Recombination between different strains of herpes virus type 1. Kurume Med. J., 20, 149-157.

Yamamoto, S., KabUta, H. and NaKagawa, Y. (1972 a). Mutants of herpes simplex virus I. Isolation and properties of mutants characterized by plaque size and cytopathogenicity. Kurume Med. J., 19, 23-31.

Yamamoto, S., Kabuta, H. and Suenaga, Y. (1972 b). Mutants of herpes simplex virus II. IDU-resistant mutants and a preliminary experiment on genetic recombination. Kurume Med. J., 19, 237-243. 